\title{
Emotional Intelligence of Kindergarten Principals in Amman
}

\author{
Abdul-Raouf Hamid Al-Yamani ${ }^{1}$ \\ ${ }^{1}$ Department of Child Education, Al-Isra University, Jordan \\ Correspondence: Abdul-Raouf Hamid Al-Yamani, Department of Child Education, Al-Isra University, Jordan.
}

Received: September 20, 2020

Accepted: November 12, 2020

Online Published: December 31, 2020

doi:10.5539/mas.v15n1p78

URL: https://doi.org/10.5539/mas.v15n1p78

\begin{abstract}
This study aimed to reveal the level of emotional intelligence and its dimensions: self-awareness, emotional management, empathy, and social skills, as well as revealing the significant differences in the degrees of emotional intelligence and its dimensions that are attributed to experience, educational level, and social status among kindergarten administrators in Amman. A scale of emotional intelligence was prepared to ensure validity and reliability to achieve the objectives of the study, and it was applied to a sample of (136) female managers. After using the arithmetic averages, the one-way analysis of variance, and the (T) test, the results are as follows:

- The level of emotional intelligence of the female managers was high.

- Significant differences were found in the overall degree of emotional intelligence and its dimensions attributable to more experienced managers' experience.

- There were no significant differences in the overall degree of emotional intelligence and its dimensions due to the educational level.

- There were no significant differences in the overall degree of emotional intelligence and its dimensions due to social status.
\end{abstract}

Keywords: emotional intelligence, kindergarten principals

\section{Introduction}

School principals face multiple challenges that threaten their job performance and emotional competence, and their negative attitudes towards administration evidence this. The size of the professional pressures that the school administration profession imposes on them, as a result of this situation, an increased focus has been placed on the factors that increase the chances of success of school principals, and positively affect their job performance, and among the most important factors for the success of school leadership is experience and intelligence in general. In particular, the focus has been on school administrators' emotional intelligence as a decisive factor in their success (Potter, 2011).

Effective and distinguished leaders have a high degree of emotional intelligence. Emotionally intelligent leaders promote success in themselves and their followers by recognizing and managing their emotions and the feelings of others (Goleman, 1995); Singh (2008) believes that the emotional intelligence of leaders is twice as important than intelligence or experience in predicting the success of leaders and managers in their job performance. That is why researchers find that a leader's success is linked to his emotional intelligence level and not just to his mental intelligence. When the institution director succeeds in spreading positive emotions in the work atmosphere, performance improves, and production increases (El-Ayiti, 2010). And the fact that emotional intelligence is one of the secrets of professional success, it has been interested in psychologists and management, as emotional intelligence began to be studied as one of the skills and concepts of social intelligence, which was initially taught by Thorndike in the twenties of the last century. Thorndike (1920) defined the concept of social intelligence as the ability to act wisely in human relations." In the 1980s, Bar-On (2006) coined the term emotional intelligence as an independent concept. In the 1990s, Salovey \& Mayer (1990) and Goleman (1995) used the term emotional intelligence to describe an individual's ability to recognize and regulate emotions within himself and others. Greenockle (2010) believes that emotional intelligence throughout this stage of conceptual development is associated with personal competence, happiness, and success.

Emotional intelligence is one of the most recent concepts in the field of psychology and the field of multiple intelligences, which has an impact on an individual's life, thinking, and relationships with others and its effect is 
not limited to the individual but extends to the institution in which he works, as it affects it according to its different activities (Al-Shaya \& Al-Mutairi, 2109).

Emotional intelligence is based on the idea of its goal, that the success of an individual in social or professional life does not depend on what the individual has of mental abilities only (cognitive intelligence), but it is also based on the emotional and social skills that he possesses, which together constitute the components of this type of intelligence (Karademir, Acak, \& Devecioglu, 2010).

The definitions of emotional intelligence have varied, so (Mayer and Salovey) defined it as a group of social intelligence elements that includes the ability to control an individual's emotions and feelings, distinguish between them, and empathize with others. Shapiro (2005) and Goleman GOLEMAN (1998) refer to emotional intelligence as the individual's ability to recognize with his feelings and the feelings of others, motivating himself, and effectively managing his emotions and relationships with others. Gardner defines it as the ability to empathize with others, organize and understand feelings, and understand others' hidden feelings. Hassouna (2006) and Al-Otaibi (2002) defined emotional intelligence as a set of abilities related to the individual's ability to deal with his emotions and feelings as well as dealing with the feelings of others, (Ibrahim, 2005) defines it as a set of personal traits and social and emotional skills that enable an individual to understand the feelings and emotions of others.

Through the previous definitions, we note that the traits of emotional intelligence can be summarized as follows:

- It's part of social intelligence

- $\quad$ Managing, understanding, and realizing emotions

- Skills in how a person interacts with others and understands their emotions

Emotional intelligence is a relatively modern concept that has clear and important effects on everyone's life, thinking, relationships, and emotions. The importance of emotion is evident in thinking, whether it is through making wise decisions or in providing us with the opportunity to think in clarity if it is taken into account that the emotion if strengthened, corrupts our ability to think sound and reach correct decisions (Goleman, 2000).

Emotional intelligence is considered one of the variables of social effectiveness and competence, which stands behind the high level of leaders' performance of the tasks assigned to them. The consequent improvement in the performance of the working individuals for their roles and its positive reflection on their productivity, emotional intelligence is the description by which a person is born. It is an established queen in our neurological data, but it varies in impact from one person to another (Al-Borini, 2006).

It should also be noted that emotional intelligence plays a major role in school administration, as the emotional smart kindergarten director can influence and control the teachers. She can establish good relationships with them and benefit from their reactions and feelings. It is rare for teachers to be influenced only mentally, but feelings and emotions have a prominent role that almost outweighs the role that the mental side plays in this regard. Therefore, the director needs emotional skills more than mental abilities to influence the teachers and achieve professional success in the organization; here, emotional intelligence plays a big role in providing a school climate full of enthusiasm and successful management, and this also helps the institution's management to create a common vision for the institution that defines the future of that institution. It defines its work plans and future goals, so that it can move from those current circumstances to a successful future vision that contributes to a successful role in achieving future goals easily (Hussein \& Hussein, 2006).

The emotional intelligence of kindergarten administrators contributes to the educational process's success and affects the increase in the percentage of students' academic achievement. The emotional intelligence of the principals ensures the better progress of the educational process; this contributes to the development of female teachers' performance as well as increases success and creativity rates, as the principal is the most important pillar on which the kindergarten depends if she is correct, the educational environment is fully correct. Therefore, kindergarten principals must possess emotional intelligence skills that help them as administrators and professionals in dealing with administrative situations, problems, and obstacles with the least possible effort and time (Henry \& Hope, 2014).

In this regard, a group of studies indicates the importance of emotional intelligence as a predictor of an individual's success at the professional and leadership levels, so a study (Hong, 2005) indicated that emotional stability is one of the most important factors for successful leadership. The study (Beavers, 2005) indicated that school leaders distinguished by high achievement have high emotional intelligence. The studies of (The 60, 2009) and McKee (2008) found a positive relationship between emotional intelligence in its various dimensions and successful leadership, Hussein (2004) indicated that emotional intelligence contributes to predicting the 
performance of the teacher in the elementary stage. The study (Al-Anani, 2014) found that emotional intelligence predicts the pattern of democratic and diplomatic leadership.

\section{The most prominent theories and models explaining emotional intelligence:}

\section{1) Mayer and Salovey theory}

Mayer and Salovey argue that the origins of emotional intelligence date back to the eighteenth century, when psychologists divided the mind into three sections: knowledge, emotion, and motivation (Alwan, 2011). Researchers Mayer and Salovey are considered the first to use the term emotional intelligence in 1990, as they considered that emotional intelligence is part of social intelligence, which includes the individual's awareness of his emotions and the emotions of others and their perception, and the ability to distinguish between emotions, their expression, and organization. The researchers assumed that there are individual differences between people in processing emotional information, so the individual's ability to recognize his own emotions and others' emotions and his ability to employ this information increases his ability to solve life problems facing him (Muhammad, 2014).

Mayer and Salovey defined emotional intelligence as the ability of the individual to know his feelings and emotions exactly as they occur, his knowledge of the feelings of others, his ability to control his emotions, his sympathy with and sense of others, and his motivation to make smart decisions, and the two researchers in their theory reached the following dimensions of emotional intelligence: (Mayer \& Salovey, 1990).

A. Emotion awareness: Is the ability of the individual to perceive and express one's feelings.

B. The use of emotions: The individual can differentiate between different emotions.

C. Understanding and analyzing emotions

D. It is the individual's ability to understand complex emotions such as feeling joy and sadness simultaneously.

E. Managing emotions: the ability of the individual to manage self-emotions and the feelings of others, and control the individual to circulate negativity, and change the mood.

\section{2) Goleman's theory}

Goleman (1995), based on Mayer and Salovey's work, presented a vision of this intelligence's nature and its life cycle in writing emotional intelligence. Goleman assumed that emotional intelligence is an ability that can be trained and taught, and he divided emotional intelligence into two parts: the personal competence section: related to the individual's understanding and awareness of his emotions, and the social competence section: related to understanding and realizing the emotions of others. Goleman defined emotion as a state of emotion that transmits ideas to others (Alwan, 2011).

Goleman defined emotional intelligence as the individual's ability to recognize his feelings and others' feelings, motivate ourselves, and effectively manage our emotions and our relationships with others (Samaduni, 2007). Goleman defined the dimensions of emotional intelligence as follows:

1. Self-awareness: It is the individual's knowledge of his inner states and sources, including (emotional awareness, self-evaluation, and self-confidence).

2. Managing emotions: the ability of the individual to manage his actions, thoughts, and feelings in a compatible and flexible manner across different situations, control negative emotions and convert them into positive emotions, and act efficiently in emergencies.

3. Self-motivation: it means that emotional intelligence greatly affects other abilities, positively or negatively, because the individual's emotional state affects his mental abilities and his performance in general.

4. Empathy: It means the individual's knowledge and awareness of others 'feelings and emotional harmony with others.

5. Social skills: It means good and effective dealing with others through knowing and understanding their feelings.

\section{3) Gardner's theory of multiple intelligences as a source of emotional intelligence}

Gardner believes that success in life requires a variety of intelligences. Gardner suggested eight types of intelligences, which are (linguistic intelligence, logical intelligence, movement intelligence, spatial intelligence, musical intelligence, natural intelligence, personal intelligence, and social intelligence), emotional intelligence is 
considered a mixture between personal intelligence and social intelligence, the first reflects the ability of the individual to understand himself, feelings and motives. In contrast, the second reflects the ability of the individual to understand the feelings of others and deal with them (Tawfiq, Khalaf, 2009).

\section{4) Bar-On Model}

Bar-On prepared his model in emotional intelligence in 1997, and he used the term (emotional quotient) for the first time; this model went through a number of improvements until he reached a picture released in 2006 under the name of the Bar-On model for emotional-social intelligence.

Bar-On defined emotional intelligence as a group of emotional, personal, and social capabilities that affect the individual's conditioning of life's stressors (Al-Rashidi, 2018).

Bar-on (2000) defined the dimensions of emotional intelligence as follows:

A. The personal dimension: the set of competencies that help the individual to deal with himself successfully (self-awareness, affirmation, self-esteem, and independence).

B. The social dimension (between persons): the set of capabilities that enable the individual to establish successful relationships and positively influence others.

C. Adaptation: the set of abilities that enable the individual to successfully adapt to life and its requirements (testing realism, flexibility, and problem-solving).

D. Stress Management: The group of abilities that help an individual to manage stress, self-control, and not impulsivity (bear stress and control impulsivity).

E. Mood: the set of abilities that help an individual perceive and change their mood (optimism and happiness).

In the current study, the researcher believes that emotional intelligence consists of four dimensions:

1. Self-awareness: the ability of an individual to know his feelings and use this knowledge in his decisions.

2. Managing emotions: the individual's ability to control his emotions and convert negative emotions into positive ones.

3. Empathy: the ability of the individual to feel for others and respond to their needs.

4. Social skills: the individual's ability to take responsibility, understand others, and communicate with them.

\subsection{Study Problem}

The theorists on the subject of emotional intelligence such as Goleman (Goleman, 1995) have indicated that cognitive intelligence does not constitute more than $20 \%$ of the factors for an individual's success in professional life while $80 \%$ of success in professional life depends on the individual possesses other intelligences, the most important of which is emotional intelligence. This gives the topic of emotional intelligence great importance in study and research. And in view of what studies have indicated that emotional intelligence predicts professional and administrative success, and given the importance of the kindergarten director and her role in managing work and improving the level of performance, organizing the interaction between the kindergarten with its various elements of teachers, administrators, workers, children, and the surrounding community, and creating an appropriate climate to increase the effectiveness of the roles of individuals surrounding the child because they have a direct impact on him, so the kindergarten director must have a lot of skills that enable her to deal intelligently with emergency situations, including intelligence Emotional. And given the researcher's interest in the field of childhood in addition to the importance of the topic of emotional intelligence and its relative novelty in the theoretical field, and the researcher's failure to notice any Arab or local study that dealt with this intelligence on kindergarten principals specifically, and that most studies in the field of childhood dealt with this type of intelligence on teachers, such as the study (Leonard, 2003), the study (Jarad, 2013), (Atoum, 2014), (Memon, 2015), and Ali (2018).

For all of the above, this study came to reveal the level of emotional intelligence and the differences attributed to experience, educational level, and social status of kindergarten administrators in the capital, Amman.

\subsection{Objectives of the Study}

This study aimed to:

Identifying the degree of emotional intelligence of kindergarten administrators in Amman. 
Disclosure of differences in emotional intelligence among kindergarten administrators in Amman due to experience, educational level and marital status.

\subsection{Study Questions}

1. What is the level of emotional intelligence among the principals of kindergartens in Amman?

2. Are there statistically significant differences at a level of (0.05) or less in emotional intelligence among kindergarten principals in Amman due to years of experience?

3. Are there statistically significant differences at a level of $(0.05)$ or less in emotional intelligence among kindergarten administrators in Amman due to the educational level?

4. Are there statistically significant differences at a level of (0.05) or less in emotional intelligence among kindergarten administrators in the city of Amman due to marital status?

\subsection{The Study Importance}

The topic's importance: This study derives its importance in dealing with the concept of emotional intelligence and its dimensions, which is considered a relatively modern concept.

\section{The importance of the target group:}

- Targeting the category of kindergarten principals, a group that deserves attention and research because they have a great role in developing their institutions, as they play an effective role in planning and enhancing opportunities for cooperation and communication (Jefferson, 2006).

Modernity and scarcity of studies in the field: The researcher did not find studies at the local and Arab level according to the researcher's knowledge - that studied emotional intelligence among kindergarten principals. Most of the studies dealt with the level of emotional intelligence among school teachers, such as the study (Atoum, 2014) and Umrah (2014), and there is one study that revealed the level of emotional intelligence of kindergarten teachers (Maymon, 2015).

- This study can benefit Arab libraries and researchers in the field of childhood in conducting training programs to develop this type of intelligence among kindergarten principals.

\subsection{Terminology of Study and Procedural Definitions}

Emotional intelligence: Goleman (1995) defines it as a set of skills that enable an individual to live more effectively and include self-awareness, emotional management, perseverance, enthusiasm, emotional knowledge, empathy, and social communication.

Ghobari and Abu Shairah, (2010) defines it as the intelligent use of emotions. A person can make his emotions work for him by thinking in ways that increase the chances of success, whether in work, school, or life in general. In this study, emotional intelligence is the kindergarten director's ability to effectively manage to stem from understanding herself, recognizing her feelings and the feelings of others, and managing her feelings and her relationships with others. This is expressed operationally by the degree that the director obtains on the emotional intelligence scale in its dimensions: self-awareness, emotional management, self-motivation, empathy, and social skills, which is designed for this study.

Kindergarten director: She is the supervisor of the administration's operations in the kindergarten by organizing the activities of children and all its employees to ensure the success of the educational process and achieve its goals in the kindergartens in Amman (Al-Anani, 2018).

Kindergartens: are the educational institutions in the city of Amman to which children from the age of (3-6) years are enrolled.

Amman: It is the largest city in the Hashemite Kingdom of Jordan and its capital.

\subsection{The Study Limitations}

Human Limits: The current study was limited to kindergarten principals in Amman.

Spatial Limits: The current study was limited to the city of Amman.

Temporal Limits: The study was applied during the first semester of the year 2020/2021.

As for the study's limitations, they are limited to the sample and its specifications and to the study instrument whose validity and reliability have been ascertained. 


\section{Previous Studies}

Al-Borini (2006) conducted a study to identify the level of emotional intelligence of primary school principals in the capital Amman and its relationship to their level of organizational performance. The study sample consisted of (100) principals from private schools in the city of Amman, the results showed a high level of emotional intelligence among managers from the teachers' point of view, and the results showed statistically significant differences in the level of emotional intelligence among managers due to the gender variable and in favor of females, to the educational qualification variable, and in favor of the higher qualification.

Jokhb (2009) conducted a study aimed at revealing the relationship between emotional intelligence and professional harmony in light of demographic variables in a sample of secondary school teachers in Riyadh, and to answer the study questions; the relational descriptive method was used, as the sample consisted of (398) female teachers in the secondary stage in Riyadh, Saudi Arabia. The emotional intelligence scale and the occupational compatibility scale were applied to them; the study revealed the existence of a positive correlation between emotional intelligence and professional harmony, differences in emotional intelligence were found due to specialization, in the interest of the humanities, in experience and in favor of more years of experience, social status and in favor of married women.

Alston (2009) conducted a study that revealed the relationship of emotional intelligence to successful leadership. The sample consisted of (241) individuals. The results revealed that emotional intelligence plays a major role in successful decision-making and that this intelligence is very important for the success of leaders in the organizations in which they work.

(Al-Harahsheh, 2013) conducted a study aimed at identifying the degree of emotional intelligence among the school directors of the Directorate of Education of the Qasbah of Mafraq Governorate in Jordan, and the effect of gender, academic qualification, and years of service on the responses of the study sample, the study sample consisted of (223) male and female teachers. The study reached the following results: The degree of emotional intelligence was high, on the tool as a whole and on all fields except for the field of emotion management, it came with a moderate degree, the study also showed that there are no statistically significant differences in the responses of the study sample individuals due to the variable of gender and academic qualification. The study results also showed that there were no statistically significant differences in the responses of the study sample individuals due to the years of experience variable on the tool as a whole and on all fields except for the empathy field. The study results showed that there are statistically significant differences in the responses of the study sample individuals due to the variable of years of service and in favor of the average service.

Al-Anani (2014) conducted a study aimed at identifying the levels of emotional intelligence and leadership styles and determining the effect of gender, age, and educational level on emotional intelligence and leadership style among teachers; the study also aimed to answer the following question: Can emotional intelligence predict leadership styles? The study sample consisted of (260) male and female teachers who work in kindergartens and basic classes in the Central Jordan Valley. The results concluded that the level of emotional intelligence and leadership styles among teachers was average. Statistically, significant differences appeared in emotional intelligence according to the gender variable in favor of females, and to the age variable in favor of the younger, and there were no differences in emotional intelligence and leadership styles due to the educational level variable, as emotional intelligence predicted its components with the two types of democratic and diplomatic leadership.

Al-Umrah (2014) conducted a study to identify the level of emotional intelligence and its relationship to the effectiveness of the leader among the principals of the Petra and Wadi Al-Sir Education Schools in Jordan, the sample of the study consisted of (102) managers and directors. The results indicated that the level of emotional intelligence among school principals was moderate. The results indicated the existence of statistically significant differences in the level of emotional intelligence: Gender in favor of males, an academic qualification in favor of master's holders, school level in favor of basic schools, experience in favor of more experience, and the absence of statistically significant differences attributable to the scientific qualification variable in the degree of evaluation of the leader's effectiveness, the results also indicated a correlation between the level of emotional intelligence and the degree of effectiveness of the leader.

Maymoun (2015) conducted a study aimed at revealing the level of emotional intelligence among kindergarten teachers in the city of M'sila, the study found that the level of emotional intelligence among kindergarten teachers is high, especially in the area of empathy. It also found that there are no statistically significant differences in the level of emotional intelligence among Riyadh teachers in M'sila city due to variables: age, marital status, and educational qualification. 
Abu Al-Khair (2018) conducted a study to identify the level of emotional intelligence of principals and its relationship to improving the performance of school principals in the lower basic stage of the Relief Agency in the West Gaza region from the point of view of the supervisors. The study found that the level of emotional intelligence of primary school principals in the West Gaza Educational Zone of the UNRWA from the supervisors' point of view was average, and a statistically significant correlation was found between the level of emotional intelligence of managers and the improvement of their performance level. And there were no significant differences in the level of managers' emotional intelligence due to the variables of gender and experience.

Jubran and Saleh (2018) conducted a study that attempted to reveal the degree to which school principals practice emotional intelligence and its relationship to their leadership styles. (80) Principals were chosen by a simple random method from school principals in Irbid, Jordan. Two tools were used: the emotional intelligence/leadership styles questionnaire. The results showed that the degree of school principals 'practice of emotional intelligence was highly appreciated. And that the most practicing leadership styles have a democratic style, and it came in the first place, followed by the trained style. The results showed that there were no statistically significant differences in the degree of school principals 'practice of emotional intelligence due to the variables of gender, academic qualification, and experience. There were no statistically significant differences in the application of leadership styles due to the effect of gender, educational qualification, and experience variables, and the results revealed a positive, statistically significant relationship between the practice of school principals of emotional intelligence and all leadership styles, except for the forced pattern.

Turk \& Wolfe (2019) conducted a study that tried to reveal levels of emotional intelligence and psychological resilience in school principals from their point of view. The study sample consisted of (26) principal and assistant principal of a school in southeastern Pennsylvania. Three measures were applied: the emotional intelligence scale, the psychological flexibility scale, and the leadership scale. The study results revealed the existence of high levels of emotional intelligence among school principals and the existence of statistically significant differences in the level of emotional intelligence among school principals attributed to years of experience in favor of those with the most experience. The results also revealed a positive association between emotional intelligence, psychological flexibility, and leadership among managers.

Freej's study (2019) aimed to reveal the level of emotional intelligence among private school principals in Beirut and its relationship to human relations within the school in light of some variables. The study sample consisted of (20) principals from several private high schools in Beirut and (269) teachers from the same schools. The Masket Emotional Intelligence Scale and the Teacher Attitude Questionnaire were used. The results showed a moderate level of emotional intelligence for the managers and the existence of a positive correlation between emotional intelligence and human relationships within the school, and the results revealed that there are no statistical differences in emotional intelligence attributable to the principal's age, gender, and years of experience.

\subsection{Commenting on Previous Studies}

Through a review of previous studies, the following can be observed:

1. Emotional intelligence represents an important dimension of the educational and administrative side.

2. Several studies have been concerned with the relationship between emotional intelligence and teachers' professional compatibility, such as a study (Khojab, 2009).

3. Aliston (2009) and (Al-Amarat, 2014) studies show the relationship between emotional intelligence and successful leadership.

4. (Al-Burini, 2006), (Harahsheh, 2013) and (Abu Al-Khair, 2018) studied the level of primary school principals' emotional intelligence.

5. The places in which the studies were conducted varied, so the study (Alston, 2009) was conducted in Florida in the United States of America, and in the Arab world as a study (Khujj, 2009) was conducted in the Kingdom of Saudi Arabia. As for locally in the Hashemite Kingdom of Jordan, it was conducted as a study (Al-Anani, 2014) and (Al-Amarat, 2014) and (Alborini, 2006).

6. The samples of studies varied, some of which were on secondary school teachers such as the study (Khoujb, 2009), and some were on school administrators such as the study (Abu Al-Khair, 2018) and (Al-Omarat, 2014), and there are only two studies on kindergarten teachers and not the principals. (Al-Anani, 2014) and (Memon, 2015). 
7. This study benefited from previous studies in knowing the theoretical frameworks for emotional intelligence and designing the study scale.

8. What distinguishes the current study from previous studies is that it dealt with emotional intelligence among kindergarten administrators in the capital, Amman, and using a scale designed by the researcher.

\section{Methodology and Procedures}

This part includes the steps involved in implementing the current study in terms of the method, sample, tool, study application procedures, and its variables.

\subsection{Study Approach}

The study used the descriptive survey approach, as it aimed to identify the level of emotional intelligence of kindergarten administrators in light of variables: experience, educational level, and social status.

\subsection{The Study Population}

The study population consisted of all kindergarten principals in Amman, who numbered (915) principals in the year 2020/2021.

\subsection{The Study Sample}

The study sample consisted of (136) female principals who were at the top of their work in the academic year 2020/2021 in the kindergartens in the city of Amman. They were chosen on a random basis with a percentage of $(15 \%)$. Table (1) shows the study sample's distribution according to the variables: experience and educational level, and marital status.

Table 1. Distribution of the study sample of principals who are on the job in the academic year 2020/2021 in kindergartens in Amman, distributed according to experience, educational level, and marital status

\begin{tabular}{llll}
\hline Variable & Variable class & Repetition & Percentages \\
\hline \multirow{4}{*}{ Experience } & Less than 5 years & 15 & 11.0 \\
& Less than 10 years & 28 & 20.6 \\
& 10 years or more & 93 & 68.4 \\
& Total & 136 & 100.0 \\
\hline \multirow{4}{*}{ Educational } & Bachelor & 75 & 55.1 \\
level & Higher diploma & 25 & 18.4 \\
& Postgraduate & 36 & 26.5 \\
& Total & 136 & 100.0 \\
Social status & Single & 31 & 22.8 \\
& Married & 105 & 77.2 \\
& Total & 136 & 100.0 \\
\hline
\end{tabular}

\subsection{The Study Tool}

To achieve the objectives of the study, the Emotional Intelligence Tool was prepared after reviewing the theoretical literature and available measures in this field, such as: (Mayer \& Salovey, 1990), (Goleman, 1995), (Othman \& Rizk, 2001) and Al-Anani (2014). The study tool consisted of four dimensions: self-awareness, managing emotions, empathy, and social skills.

The kindergarten principals made the response on the tool's paragraphs according to a five-dimensional scale: (Always, Expensive, Sometimes, Rarely, Never), the score (5) expresses the highest levels of emotional intelligence, while the score (1) expresses the lowest level of emotional intelligence, an average level, the levels of the averages were divided into three levels: the low level of emotional intelligence, with averages ranging between $(1-2.33)$, the average level of emotional intelligence, and its averages ranging between (2.34 - 3.67), and the high level of emotional intelligence, and its levels ranged between (3.68 - 5). An exploratory study was conducted on (30) kindergarten directors from the capital Amman Governorate in Jordan from outside the study sample to verify the validity indicators of the construction of the scale, as the correlation coefficients between the paragraphs and the field to which they belong were calculated, and it was found that all the sections have significant correlation coefficients Statistically, they are as follows: 
Table 2. Construct validity indicators represented by correlation coefficients and statistical significance between the paragraph and the dimension to which it belongs in the emotional intelligence scale

\begin{tabular}{|c|c|c|c|c|c|c|c|c|c|c|c|}
\hline \multicolumn{3}{|c|}{ Self-awareness dimension } & \multicolumn{3}{|c|}{ Managing emotions dimension } & \multicolumn{3}{|c|}{ Dimension of empathy } & \multicolumn{3}{|c|}{ Social skills dimension } \\
\hline Item & correlation & Significance & Item & correlation & Significance & Item & correlation & Significance & Item & correlation & Significance \\
\hline 1 & $.535 * *$ & .002 & 11 & $.551 * *$ & .002 & 19 & $.666^{* *}$ & .000 & 29 & $.506^{* *}$ & .004 \\
\hline 2 & $.430 *$ & .018 & 12 & $.540 * *$ & .002 & 20 & $.665^{* *}$ & .000 & 30 & $.591 * *$ & .001 \\
\hline 3 & $.824 * *$ & .000 & 13 & $.666^{* *}$ & .000 & 21 & $.634 * *$ & .000 & 31 & $.743 * *$ & .000 \\
\hline 4 & $.684 * *$ & .000 & 14 & $.500 * *$ & .005 & 22 & $.633 * *$ & .000 & 32 & $.693 * *$ & .000 \\
\hline 5 & $.600 * *$ & .000 & 15 & $.567 * *$ & .001 & 23 & $.642 * *$ & .000 & 33 & $.508^{* *}$ & .004 \\
\hline 6 & $.577 * *$ & .001 & 16 & $.718^{* *}$ & .000 & 24 & $.587 * *$ & .001 & 34 & $.523 * *$ & .003 \\
\hline 7 & $.704^{* *}$ & .000 & 17 & $.895^{* *}$ & .000 & 25 & $.721 * *$ & .000 & 35 & $.833 * *$ & .000 \\
\hline 8 & $.560 * *$ & .001 & 18 & $.705^{* *}$ & .000 & 26 & $.622 * *$ & .000 & 36 & $.594 * *$ & .000 \\
\hline 9 & $.745^{* *}$ & .000 & & & & 27 & $.777 * *$ & .000 & 37 & $.774 * *$ & .001 \\
\hline 10 & $.663^{* *}$ & .000 & & & & 28 & $.594 * *$ & .001 & 38 & $.622 * *$ & .000 \\
\hline & & & & & & & & & 39 & $.789 * *$ & .000 \\
\hline
\end{tabular}

* Significant at significance level (0.05)

* Significant at significance level (0.01)

The construct validity indicators for the domains with each other and with the total score of the emotional intelligence scale were also calculated by calculating the correlation coefficients between them, as it was found that all the correlation coefficients between the domains and the total degree are statistically significant, as follows:

Table 3. Correlation coefficient between domains with each other and with the overall score of the emotional intelligence scale

\begin{tabular}{|c|c|c|c|c|c|}
\hline Field & $\begin{array}{l}\text { Self-awareness } \\
\text { dimension }\end{array}$ & $\begin{array}{l}\text { Managing } \\
\text { emotions } \\
\text { dimension }\end{array}$ & $\begin{array}{l}\text { Dimension } \\
\text { of empathy }\end{array}$ & $\begin{array}{l}\text { Social skills } \\
\text { dimension }\end{array}$ & Total marks \\
\hline Self-awareness dimension & 1 & & & & \\
\hline $\begin{array}{l}\text { Managing emotions } \\
\text { dimension }\end{array}$ & $.533 * *$ & 1 & & & \\
\hline Dimension of empathy & $.380^{*}$ & $.517 * *$ & 1 & & \\
\hline Social skills dimension & $.432 *$ & $.430 *$ & $.650 * *$ & 1 & \\
\hline Total marks & $.702 * *$ & $.774 * *$ & $.831 * *$ & $.768^{* *}$ & 1 \\
\hline
\end{tabular}

3.4.1 The Reliability of the Emotional Intelligence Scale

An exploratory sample consisting of (30) principals from kindergartens from the capital, Amman, Jordan, were selected from outside the study sample. Then they have applied again after (14) days and calculate the reliability by test and return (Test-Retest) by computing the Pearson correlation coefficient, where the reliability of the total return of the emotional intelligence scale reached a rate of $(0.908)$. The reliability on the prescale was also calculated using the Cronbach (alpha) equation for internal consistency, where the total stability of Cronbach's alpha of the emotional intelligence scale reached (0.918), and the following table shows the proportions of reliability. 
Table 4. Repetition reliability coefficients and internal coherence reliability Cronbach alpha for domains and the overall score of the emotional intelligence scale

\begin{tabular}{lll}
\hline Questionnaire axes & \multicolumn{2}{l}{ Student Portrait } \\
\cline { 2 - 3 } Self-awareness dimension & Replay reliability & Internal consistency \\
\cline { 2 - 3 } Managing emotions dimension & 0.886 & 0.830 \\
Dimension of empathy & 0.876 & 0.801 \\
Social skills dimension & 0.860 & 0.849 \\
Total marks & $\mathbf{0 . 9 0 8}$ & 0.863 \\
\hline
\end{tabular}

\subsection{Study Procedures}

The researcher took the following actions:

1. Determine the population and sample of the study from the directorates of the capital, Amman.

2. Access the theoretical literature and previous studies related to emotional intelligence.

3. Prepare the study tool and making sure of its validity and reliability.

4. Apply the tool to the study sample.

5. Unpacking the data and extracting the results.

6. Answer study questions, analyze and discuss results, and make recommendations.

\subsection{Study Variables}

- Experience has three levels ( 1 - less than 5 years), (5 - less than 10 years), (10 years and more).

- Educational level and has three levels (Bachelor, Higher Diploma, and Postgraduate studies).

- Marital status and has two levels (single, married).

- Emotional intelligence has four dimensions (self-awareness, emotional management, empathy, and social skills).

\subsection{Statistical Treatment}

- Pearson correlation coefficient and Cronbach alpha to determine the reliability of the instrument.

- Arithmetic means and standard deviations to reveal the level of emotional intelligence and its dimensions.

- Single-point analysis of variance to reveal differences attributable to experience and educational level.

- $\quad$ (T) test to detect differences attributed to marital status.

\section{The Study Results}

The first question: "What is the level of emotional intelligence among the principals of kindergartens in Amman?

To answer this question, arithmetic averages and standard deviations were calculated for the level of kindergarten principals' emotional intelligence in Amman, and Table (5) illustrates this.

Table 5. The arithmetic means and standard deviations of the emotional intelligence level of the kindergarten directors arranged in descending order according to the arithmetic means

\begin{tabular}{llllll}
\hline Rank & Number & Dimension & $\begin{array}{l}\text { Arithmetic } \\
\text { average }\end{array}$ & $\begin{array}{c}\text { Standard } \\
\text { deviation }\end{array}$ & Level \\
\hline 1. & 3 & Sympathy & 4.43 & .630 & High \\
2. & 1 & SELF AWARENESS & 4.13 & .544 & High \\
3. & 4 & Social skills & 4.12 & .523 & High \\
4. & 2 & $\begin{array}{l}\text { Managing emotions } \\
\text { The total score of emotional } \\
\text { intelligence }\end{array}$ & 3.84 & .617 & High \\
& & $\mathbf{4 . 1 5}$ & $\mathbf{. 4 9 8}$ & High \\
\hline
\end{tabular}


Table (5) shows that the level of emotional intelligence in kindergarten directors, arranged in descending order according to the arithmetic means, was high, and all dimensions were high, and the arithmetic average of the total score for the level of emotional intelligence was (4.15) with a standard deviation (0.498). This result is attributed to the fact that female managers strive to obtain the best result for the tasks required of them, and that they possess the ability to perform well, and given the importance of the Riyadh stage and its specificity, managers are carefully selected and work on their continuous development, this result is consistent with the study of (Al-Burini, 2006), (Harahsheh, 2013), (Maymoun, 2015), (Turk \& Wolfe, 2019), and (Gibran \& Saleh, 2018). It disagreed with a study (Al-Omarat, 2014), (Abu Al-Khair, 2018), and (Freej, 2019), where the level of emotional intelligence was moderate. The third dimension, which is: "empathy," came first among the fields, with an arithmetic mean (4.43) and a standard deviation (0.630). This result is attributed to the fact that managers are keen on others' feelings as an input to guide them, and emotional intelligence is considered a social intelligence that appears more evident through dealing with others and sympathizing with them. This result is consistent with the study (Maymon, 2015), while the first dimension: "Self-awareness," came in the second rank, with an arithmetic mean (4.13) and a standard deviation (0.544); this result is attributed to the fact that the skills of self-awareness are among the easiest skills of emotional intelligence, and the manager understands them well. The fourth dimension: "Social Skills," came in the third rank, with an arithmetic mean (4.12) and a standard deviation (0.523). This result is attributed to the fact that managers are keen on the feelings of others. And emotional intelligence is considered a social intelligence that appears in the manager's interaction with others. The fact that the kindergarten director's administrative center requires her to deal with various society segments requires their possession of social skills. While the second dimension came in the last rank, which is: "emotions management" in the second rank, with an arithmetic mean (3.84) and a standard deviation (0.617). Although this dimension is considered high, it received the lowest scores. The researcher attributes this result to the fact that managers deal with many people, including teachers, administrators, children, parents, and a local community; these job pressures make them unaware of adequately managing their emotions.

The second question: "Are there statistically significant differences at a level of (0.05) or less in emotional intelligence among kindergarten administrators in Amman due to years of experience?

To answer this question, arithmetic averages and standard deviations of emotional intelligence levels among kindergarten principals in Amman were calculated according to the years of experience variable, and Table (6) illustrates this.

Table 6. The differences in arithmetic averages between levels of emotional intelligence among kindergarten administrators in Amman according to the years of experience variable

\begin{tabular}{|c|c|c|c|c|c|c|}
\hline $\begin{array}{l}\text { Variable } \\
\text { class }\end{array}$ & $\begin{array}{l}\text { Descriptive } \\
\text { statistics }\end{array}$ & Self-awareness & $\begin{array}{l}\text { Managing } \\
\text { emotions }\end{array}$ & Sympathy & $\begin{array}{l}\text { Social } \\
\text { skills }\end{array}$ & $\begin{array}{l}\text { Total } \\
\text { marks }\end{array}$ \\
\hline \multirow{3}{*}{$\begin{array}{l}1-\text { Less than } \\
5 \text { years }\end{array}$} & $\begin{array}{l}\text { Arithmetic } \\
\text { average }\end{array}$ & 3.18 & 3.13 & 3.15 & 3.32 & 3.20 \\
\hline & Sample number & 15 & 15 & 15 & 15 & 15 \\
\hline & $\begin{array}{l}\text { Standard } \\
\text { deviation }\end{array}$ & .923 & .879 & .816 & .706 & .764 \\
\hline \multirow{3}{*}{$\begin{array}{l}5 \text { - Less than } \\
10 \text { years }\end{array}$} & $\begin{array}{l}\text { Arithmetic } \\
\text { average }\end{array}$ & 4.11 & 3.79 & 4.38 & 4.17 & 4.13 \\
\hline & Sample number & 28 & 28 & 28 & 28 & 28 \\
\hline & $\begin{array}{l}\text { Standard } \\
\text { deviation }\end{array}$ & .336 & .582 & .519 & .429 & .350 \\
\hline \multirow{3}{*}{$\begin{array}{l}10 \text { years or } \\
\text { more }\end{array}$} & $\begin{array}{l}\text { Arithmetic } \\
\text { average }\end{array}$ & 4.28 & 3.97 & 4.66 & 4.24 & 4.30 \\
\hline & Sample number & 93 & 93 & 93 & 93 & 93 \\
\hline & $\begin{array}{l}\text { Standard } \\
\text { deviation }\end{array}$ & .318 & .491 & .284 & .388 & .262 \\
\hline
\end{tabular}

Table (6) results show that there are apparent differences between the arithmetic averages in the fields and the total degree of emotional intelligence among kindergarten administrators in the city of Amman due to the years 
of experience variable. To determine the statistical differences, the one-way ANOVA analysis was calculated, and Table (7) explains that:

Table 7. Analysis of variance for the effect of years of experience variable on levels of emotional intelligence among kindergarten principals in Amman

\begin{tabular}{|c|c|c|c|c|c|c|}
\hline $\begin{array}{l}\text { Areas of the } \\
\text { questionnaire }\end{array}$ & $\begin{array}{l}\text { The source of the } \\
\text { contrast }\end{array}$ & $\begin{array}{l}\text { Sum of } \\
\text { squares }\end{array}$ & $\begin{array}{l}\text { Degrees } \\
\text { of } \\
\text { freedom }\end{array}$ & $\begin{array}{l}\text { Average } \\
\text { of squares }\end{array}$ & P Test & $\begin{array}{l}\text { Statistical } \\
\text { significance }\end{array}$ \\
\hline \multirow{3}{*}{ Self-awareness } & Between groups & 15.683 & 2 & 7.841 & \multirow{3}{*}{42.993} & \multirow{3}{*}{.000} \\
\hline & Within groups & 24.257 & 133 & .182 & & \\
\hline & Total & 39.940 & 135 & & & \\
\hline \multirow{3}{*}{$\begin{array}{l}\text { Managing } \\
\text { emotions }\end{array}$} & Between groups & 9.227 & 2 & 4.613 & \multirow{3}{*}{14.563} & \multirow{3}{*}{.000} \\
\hline & Within groups & 42.133 & 133 & .317 & & \\
\hline & Total & 51.359 & 135 & & & \\
\hline \multirow{3}{*}{ Sympathy } & Between groups & 29.558 & 2 & 14.779 & \multirow{3}{*}{81.947} & \multirow{3}{*}{.000} \\
\hline & Within groups & 23.986 & 133 & .180 & & \\
\hline & Total & 53.544 & 135 & & & \\
\hline \multirow{3}{*}{ Social skills } & Between groups & 11.068 & 2 & 5.534 & \multirow{3}{*}{28.533} & \multirow{3}{*}{.000} \\
\hline & Within groups & 25.795 & 133 & .194 & & \\
\hline & Total & 36.863 & 135 & & & \\
\hline \multirow{3}{*}{ Total marks } & Between groups & 15.705 & 2 & 7.853 & \multirow{3}{*}{58.682} & \multirow{3}{*}{.000} \\
\hline & Within groups & 17.797 & 133 & .134 & & \\
\hline & Total & 33.502 & 135 & & & \\
\hline
\end{tabular}

Table (7) shows that there are statistically significant differences due to the effect of the years of experience variable in the levels of emotional intelligence dimensions and the overall score of kindergarten administrators in Amman, where the statistical significance was (0.000), which is less than the level of significance (0.05), which indicates the existence of statistical differences, and to find out the direction of these differences, the Scheffe test was used, as in Table (8):

Table 8. Scheffe test results to determine the trend of statistical differences in emotional intelligence levels among kindergarten administrators in Amman according to the years of experience variable

\begin{tabular}{|c|c|c|c|c|c|}
\hline Dimension & Years of Experience & $\begin{array}{l}\text { Arithmetic } \\
\text { average }\end{array}$ & $\begin{array}{l}\text { Less than } 5 \\
\text { years }\end{array}$ & $\begin{array}{l}\text { Less than } \\
10 \text { years }\end{array}$ & $\begin{array}{l}10 \text { years or } \\
\text { more }\end{array}$ \\
\hline \multirow[t]{3}{*}{ Self-awareness } & 1- Less than 5 years & 3.18 & & & \\
\hline & 5- Less than 10 years & 4.11 & $.934^{*}$ & & \\
\hline & 10 years or more & 4.28 & $1.102 *$ & .167 & \\
\hline \multirow{3}{*}{$\begin{array}{l}\text { Managing } \\
\text { emotions }\end{array}$} & 1- Less than 5 years & 3.13 & & & \\
\hline & 5- Less than 10 years & 3.79 & $.661 *$ & & \\
\hline & 10 years or more & 3.97 & $.841 *$ & .180 & \\
\hline \multirow[t]{3}{*}{ Sympathy } & 1- Less than 5 years & 3.15 & & & \\
\hline & 5- Less than 10 years & 4.38 & $1.235^{*}$ & & \\
\hline & 10 years or more & 4.66 & $1.510^{*}$ & $.275^{*}$ & \\
\hline \multirow[t]{3}{*}{ social skills } & 1- Less than 5 years & 3.32 & & & \\
\hline & 5- Less than 10 years & 4.17 & $.854^{*}$ & & \\
\hline & 10 years or more & 4.24 & $.922 *$ & .069 & \\
\hline \multirow[t]{3}{*}{ Total marks } & 1- Less than 5 years & 3.20 & & & \\
\hline & 5- Less than 10 years & 4.13 & $.933^{*}$ & & \\
\hline & 10 years or more & 4.30 & $1.102 *$ & .170 & \\
\hline
\end{tabular}

* Significant at the significance level (0.05) 
The results of Table (8) revealed the existence of statistically significant differences due to the effect of the years of experience variable in the levels of emotional intelligence dimensions and the overall score of kindergarten administrators in Amman, and these differences came in favor of more years. There were differences between the years of experience ( 5 - less than 10 years) and ( 10 years and more) compared to ( 1 - less than 5 years), and the differences were in favor of more years of experience. This result is attributed to the fact that the overall degree of emotional intelligence and its dimensions increases with experience and that years of experience for the director represent a major component for judging their competence, wisdom, and promotion. And emotional intelligence is a skill that can be developed through experience and qualification, and this result is consistent with the study of (Woghub, 2009), (and Al-Amrah, 2014), while they differed with the study of (Harahsheh, 2013) and (Frigg, 2019), whose results revealed that there were no statistically significant differences in emotional intelligence attributable to years of experience.

The third question: "Are there statistically significant differences at a level of (0.05) or less in emotional intelligence among kindergarten administrators in the city of Amman due to the educational level?"

To answer this question, arithmetic averages and standard deviations of emotional intelligence levels for kindergarten administrators in Amman were calculated according to the educational level variable, and Table (9) illustrates this.

Table 9. The differences in arithmetic averages between levels of emotional intelligence among kindergarten administrators in Amman according to the educational level variable

\begin{tabular}{|c|c|c|c|c|c|c|}
\hline Variable class & $\begin{array}{l}\text { Descriptive } \\
\text { statistics }\end{array}$ & Self-awareness & $\begin{array}{l}\text { Managing } \\
\text { emotions }\end{array}$ & Sympathy & $\begin{array}{l}\text { social } \\
\text { skills }\end{array}$ & $\begin{array}{l}\text { Total } \\
\text { marks }\end{array}$ \\
\hline \multirow[t]{3}{*}{ Bachelor } & $\begin{array}{l}\text { Arithmetic } \\
\text { average }\end{array}$ & 4.09 & 3.84 & 4.37 & 4.17 & 4.14 \\
\hline & $\begin{array}{l}\text { Sample } \\
\text { number }\end{array}$ & 75 & 75 & 75 & 75 & 75 \\
\hline & $\begin{array}{l}\text { Standard } \\
\text { deviation }\end{array}$ & .560 & .623 & .679 & .542 & .525 \\
\hline \multirow[t]{3}{*}{$\begin{array}{l}\text { Higher } \\
\text { diploma }\end{array}$} & $\begin{array}{l}\text { Arithmetic } \\
\text { average }\end{array}$ & 4.21 & 3.87 & 4.54 & 4.08 & 4.19 \\
\hline & $\begin{array}{l}\text { Sample } \\
\text { number }\end{array}$ & 25 & 25 & 25 & 25 & 25 \\
\hline & $\begin{array}{l}\text { Standard } \\
\text { deviation }\end{array}$ & .442 & .688 & .432 & .517 & .422 \\
\hline \multirow[t]{3}{*}{ Postgraduate } & $\begin{array}{l}\text { Arithmetic } \\
\text { average }\end{array}$ & 4.13 & 3.83 & 4.48 & 4.05 & 4.14 \\
\hline & $\begin{array}{l}\text { Sample } \\
\text { number }\end{array}$ & 36 & 36 & 36 & 36 & 36 \\
\hline & $\begin{array}{l}\text { Standard } \\
\text { deviation }\end{array}$ & .580 & .567 & .639 & .488 & .500 \\
\hline
\end{tabular}

The results of Table (9) show that there are apparent differences between the arithmetic averages in the fields and the total degree of emotional intelligence among kindergarten administrators in the city of Amman due to the educational level variable, and to determine the statistical differences, the One-way ANOVA analysis was calculated, and Table (10) This explains: 
Table 10. An analysis of unilateral variance of the effect of the educational level variable on emotional intelligence levels among kindergarten principals in Amman

\begin{tabular}{|c|c|c|c|c|c|c|}
\hline $\begin{array}{l}\text { Areas of the } \\
\text { questionnaire }\end{array}$ & $\begin{array}{l}\text { The source of the } \\
\text { contrast }\end{array}$ & $\begin{array}{l}\text { Sum of } \\
\text { squares }\end{array}$ & $\begin{array}{l}\text { Degrees } \\
\text { of } \\
\text { freedom }\end{array}$ & $\begin{array}{l}\text { Average } \\
\text { of squares }\end{array}$ & P Test & $\begin{array}{l}\text { Statistical } \\
\text { significance }\end{array}$ \\
\hline \multirow[t]{3}{*}{ Self-awareness } & Between groups & .244 & 2 & .122 & .408 & .666 \\
\hline & Within groups & 39.696 & 133 & .298 & & \\
\hline & Total & 39.940 & 135 & & & \\
\hline \multirow{3}{*}{$\begin{array}{l}\text { Managing } \\
\text { emotions }\end{array}$} & Between groups & .024 & 2 & .012 & .031 & .969 \\
\hline & Within groups & 51.335 & 133 & .386 & & \\
\hline & Total & 51.359 & 135 & & & \\
\hline \multirow[t]{3}{*}{ Sympathy } & Between groups & .645 & 2 & .322 & .810 & .447 \\
\hline & Within groups & 52.900 & 133 & .398 & & \\
\hline & Total & 53.544 & 135 & & & \\
\hline \multirow[t]{3}{*}{ Social skills } & Between groups & .394 & 2 & .197 & .718 & .489 \\
\hline & Within groups & 36.469 & 133 & .274 & & \\
\hline & Total & 36.863 & 135 & & & \\
\hline \multirow[t]{3}{*}{ Total marks } & Between groups & .053 & 2 & .027 & .106 & .899 \\
\hline & Within groups & 33.449 & 133 & .251 & & \\
\hline & Total & 33.502 & 135 & & & \\
\hline
\end{tabular}

Table (10) shows that there are no statistically significant differences due to the effect of the educational level variable on the levels of emotional intelligence dimensions and the overall score of kindergarten administrators in Amman. The statistical significance in all dimensions and the overall score was higher than the significance level (0.05), indicating that there are no statistical differences between female managers with different educational levels. This result is because emotional intelligence is a personality trait that develops with experience regardless of educational level; this result confirms that kindergarten principals agree, with different educational qualifications, on the degree to which kindergarten principals practice emotional intelligence skills, and this result is in agreement with the study (Al-Anani, 2014), (Al-Umrah, 2014), (Maymon, 2015). And it disagreed with the study (Al-Burini, 2006) and (Gibran \& Saleh, 2018), which revealed the existence of significant differences in emotional intelligence attributable to the educational level variable in favor of the higher level.

The fourth question: "Are there statistically significant differences at a level of $(0.05)$ or less in emotional intelligence among kindergarten administrators in the city of Amman due to marital status?"

To answer this question, arithmetic averages, standard deviations, and a " $t$ " test for emotional intelligence levels of kindergarten administrators in Amman were calculated according to the marital status variable, and Table (11) illustrates this.

Table 11. Arithmetic averages, standard deviations, and a " $\mathrm{t}$ " test for the level of emotional intelligence for the dimensions and the overall score of kindergarten administrators in Amman attributed to the marital status

\begin{tabular}{llllllll}
\hline Scale dimensions & $\begin{array}{l}\text { Social } \\
\text { status }\end{array}$ & Number & $\begin{array}{l}\text { Arithmetic } \\
\text { average }\end{array}$ & $\begin{array}{l}\text { Standard } \\
\text { deviation }\end{array}$ & $\begin{array}{l}\text { "T" } \\
\text { value }\end{array}$ & $\begin{array}{l}\text { Degrees of } \\
\text { freedom }\end{array}$ & $\begin{array}{l}\text { Statistical } \\
\text { significance }\end{array}$ \\
\hline Self-awareness & Single & 31 & 4.04 & .712 & $-1.014-$ & 134 & .312 \\
& Married & 105 & 4.15 & .485 & & & .208 \\
Managing & Single & 31 & 3.72 & .818 & $-1.265-$ & 134 & .132 \\
emotions & Married & 105 & 3.88 & .543 & & & \\
Sympathy & Single & 31 & 4.28 & .812 & $-1.516-$ & 134 & .659 \\
Social skills & Married & 105 & 4.48 & .562 & & & \\
& Single & 31 & 4.09 & .617 & $-.443-$ & 134 & .222 \\
The total score of & Single & 31 & 4.13 & .494 & & & \\
the scale & Married & 105 & 4.17 & .431 & & & \\
\hline
\end{tabular}


Table (11) shows that there are no statistically significant differences $(a=0.05)$ in the level of emotional intelligence for the dimensions and the overall score of kindergarten administrators in the city of Amman due to the marital status, where the level of emotional intelligence does not differ between single and married managers. This result is attributed to the fact that the manager separates her marital status from her work, and the dimensions of emotional intelligence, such as empathy, social skills, and others, are human dimensions necessary for communicating with others, which must be provided in a successful manager regardless of her social status, this result differed with a study (Khujj, 2009), which revealed the existence of significant differences in emotional intelligence due to the variable of marital status in favor of married women.

\section{Recommendations}

In light of the results of the study, the researcher recommends several recommendations, the most important of which are:

- Educating citizens about the importance of emotional intelligence and the need to develop it through the media.

- Designing training programs for school principals on emotional intelligence skills to develop their abilities and setting special standards in appointing kindergarten principals.

- Conducting other studies linking emotional intelligence with other variables such as organizational culture, organizational climate, creativity, personality traits, and others.

\section{References}

Abdul Sattar, I. (2005). Emotional Intelligence. Sawahel Forum - Emotional Intelligence.

Abdul Wahid, I. (2010). The Human Brain and Emotional Intelligence. Alexandria: Dar Al-Wafaa for the World of Printing and Publishing.

Abu al-Khair, A. (2018). The level of emotional intelligence and its relationship to improving school principals' performance in the lower elementary stage of the Relief Agency in West Gaza. International Journal of Educational and Psychological Studies.

Al-Amrat, M. (2014). The level of emotional intelligence and its relationship to the leader's effectiveness among school principals in Jordan. The Jordanian Journal of Educational Sciences. Amman.

Al-Anani, H. (2014). Emotional intelligence and its relationship to leadership style among kindergarten teachers in basic schools in the Central Jordan Valley. The Educational Journal, Kuwait University.

Al-Anani, H. (2018). Leadership Intelligence for Kindergarten Directors in Amman. Journal of Social Affairs, Social Society, 13. United Arab Emirates.

Al-Borini, R. (2006). Emotional Intelligence of Private Primary School Principals in the Capital, Amman, and Its Relation to Their Administrative Performance from Their Teachers' Viewpoint. Unpublished MA Thesis, Amman Arab University, Amman - Jordan.

Al-Eity, Y. (2010). Emotional Intelligence in Management and Leadership. 5th edition, Dar Al Fikr.

Al-Rashidi, R. (2018). Emotional Intelligence and its Relation to Social Skills among Riyadh Stage Children. Published MA thesis, Kuwait University.

Al-Shaya, A., \& Al-Mutairi, A. (2019). Emotional Intelligence and its Relationship to Servant Leadership among School Leaders in Al-Mudhit Governorate from the Teachers' Perspective. International Journal of Educational and Psychological Studies, 5(2), 177-190.

Alston, D. (2009). An Examination of the relationship between emotional intelligence and leadership practices, doctors of business administration, southeastern nova university. Retrieved from https://proquest.uni.com

Alwan, A. (2011). Emotional Intelligence and its Relation to Social Skills and Attachment Patterns for University Students in Light of the Variables of Specialization and Student Gender. The Jordanian Journal of Educational Sciences.

Bar-on, R. (2000). Emotional Quotient Inventory: Technical Manual. Toronto: Multi-health systems. https://doi.org/10.1037/t14077-000

Bar-On, R. (2006). The Bar-On model of emotional-social intelligence (ESI). Psicothema, 18, 13-25.

Beavers, M. (2005). Emotional Intelligence, school leaders and high poverty middle school in the state of Virginia. Ph.D. common wealth university. Retrieved from https://proquest.uni.com 
Boussalah, K. (2018). Emotional intelligence and its relationship to professional compatibility in his sample of primary education administrators. Published MA thesis, Mohamed Boudiaf University, Algeria.

Coban, B., Karademir, T., Acak, M., \& Devecioghu, S. (2010). The emotional intelligence of students who are sitting a special-ability examination. Social behavior and personality, 38(8), 1123-1134. https://doi.org/10.2224/sbp.2010.38.8.1123

Freej, I. (2019). The emotional intelligence of the principal and its relationship to some human relations. A study of a sample of private school principals in Lebanon. The Educational Journal, 133(1), 235-273.

Ghobari, A., \& Abu Shairah, K. (2010). Mental capacities between intelligence and creativity. Amman: Arab Society Publishing Library.

Goleman, D. (1995). Emotional intelligence: Why it matters more than IQ. New York: Bantam Books.

Goleman, D. C. (1997). Working with emotional intelligence. New York: Bantam.

Greenockle, K. M. (2010). The new face in leadership: Emotional intelligence. Quest, 62(3), 260-267. https://doi.org/10.1080/00336297.2010.10483647

Harahsheh, M. (2013). Degree of emotional intelligence among school directors of the Directorate of Education of the Qasbah District in Mafraq Governorate in Jordan. Al-Manara, 19(2).

Hassouna, A., \& Saeed, M. (2006). A program to give Riyadh children some dimensions of emotional intelligence. Journal of Childhood Studies. Institute of Higher Studies for Childhood.

Henry, E., \& Hope. (2014). Principals' emotional intelligence and its impact on adequate yearly progress. Journal of Educational Leadership in Action, 209(2164), 144-200. Retrieved from https://proquest.uni.com

Hong, Y. (2005). Motivation to lead antecedent, resulting in leader emergence. M. Sc, Sant Mary.

Hussein, S., \& Hussein, T. (2006). The Emotional Intelligence of Educational Leadership, 1st Edition, Alexandria, Dar Al-Wafa for Printing and Publishing.

Iman, A. (2018). Emotional intelligence of kindergarten teachers and its relationship to some variables. Al-Mustansiriya University, College of Education, Iraq.

Jefferson, J. (2006). Changes in African American Urban high school principal's leadership behaviors in an era of no child left behind. Selon Hal University.

Joshob, A. (2009). Emotional intelligence and its relationship to professional compatibility: a study on secondary school teachers in Riyadh. Published MA thesis, Imam Muhammad bin Saud Islamic University, Riyadh, Saudi Arabia.

Jubran, A., \& Saleh, N. (2018). The Extent of Practicing Emotional Intelligence among Principals and its Relationship to Leadership Styles in Jordan. IUG Journal of Educational \& Psychological Studies, 26(2), 1-13. https://doi.org/10.12816/0049244

Leonard, A. (2003). The relationship between the Kanawha country school system's emotional intelligence competencies in West Virginia and their teacher perception of school climate dissertation Abstract International 65(8A)2841.

Maymoun, A. (2015). The level of emotional intelligence among kindergarten teachers. Published MA thesis, University of Muhammad Boudiaf, Municipality of M'sila.

Micky, H. (2008). Running head: Technology integration, emotional intelligence, and leadership. Ph.D. Fielding graduate university. Retrieved from https://proquest.uni.com

Muhammad, A. (2014). The role of kindergarten teachers in developing emotional intelligence in children. Journal of the College of Education for Girls. Jerash University.

Othman, F., \& Abdel Samie, M. (2001). Emotional intelligence, its concept, and measurement. Journal of Psychology, 15(61), 32-49.

Potter, G. (2011). A qualitative exploration of a new concept in support of good educational Leadership-Emotional intelligence. International Journal of Educational Leadership Preparation, 6(2).

Salovey, P., \& Mayer, J. D. (1990). Emotional intelligence. Imagination, Cognition, and Personality, 9, 185-211. https://doi.org/10.2190/DUGG-P24E-52WK-6CDG

Shapiro, L. (2005). How to raise a child with emotional intelligence. Greer Library. 
Singh, P. (2008). Emotional intelligence begets collegial leadership in education. The International Journal of Learning, 15(1), 24-33. https://doi.org/10.18848/1447-9494/CGP/v15i01/45575

Tawfiq, A., \& Khalaf, A. (2009). The story's effectiveness for developing the emotional intelligence of a kindergarten child. Arab Childhood Journal, 37.

Thorndike, E. L. (1920). Intelligence and its use. Harper's Magazine, 140, 227-235.

Turk, E., \& Wolfe, Z. (2019). Principal's Perceived Relationship Between Emotional Intelligence, Resilience, and Resonant Leadership Throughout Their Career. International Journal of Educational Leadership Preparation, 14(1), 147-169.

\section{Copyrights}

Copyright for this article is retained by the author(s), with first publication rights granted to the journal.

This is an open-access article distributed under the terms and conditions of the Creative Commons Attribution license (http://creativecommons.org/licenses/by/4.0/). 